\title{
EPICA Dome C 2 drilling operations: performances, difficulties, results
}

\author{
L. AUGUSTIN, ${ }^{1}$ S. PANICHI, ${ }^{2}$ F. FRASCATI ${ }^{2}$ \\ ${ }^{1}$ Laboratoire de Glaciologie et Géophysique de l'Environnement du CNRS, I'Université Joseph Fourier-Grenoble, \\ 54 rue Molire, BP 96, 38402 Saint-Martin-d'Hres Cedex, France \\ E-mail: laurent.augustin@ssec.wisc.edu \\ ${ }^{2}$ Ente per le Nuove Tecnologie, I'Energia e I'Ambiente, Centro Ricerche Brasimone, I-40032 Camugnano (BO), Italy
}

\begin{abstract}
The European Project for Ice Coring in Antarctica (EPICA) Dome C 2 (EDC2) drilling was concluded on 21 December 2005, a few metres above bedrock. The drilling was stopped both for environmental reasons and because of the drilling difficulties encountered in 'warm ice'. This paper describes in detail the progress and the performance of the EPICA drill, including the procedures needed to penetrate into 'warm ice' and their effects on core quality. Some drill technical data are also presented.
\end{abstract}

\section{INTRODUCTION}

European Project for Ice Coring in Antarctica (EPICA) Dome C drilling began in 1996/97. The set-up, drilling equipment and operation in the first five drilling seasons have already been documented (Augustin and Antonelli, 2002). EPICA Dome C 1 (EDC1), the first hole at Dome C, ended on 20 December 1998 at $783 \mathrm{~m}$ depth when the drill was deemed irretrievably stuck after several attempts to free it. In November 1999, all surface equipment was moved $10 \mathrm{~m}$ north from its original location. A new hole, EDC2, was started from the surface on 11 December 1999. By 31 January 2001, a depth of $1458 \mathrm{~m}$ had been reached. Three more seasons were needed to reach $3270 \mathrm{~m}$ depth, $16 \mathrm{~m}$ above bedrock. The challenge of the two last seasons was to drill through what we call 'warm ice' (unpublished data from International Partnership in Ice Core Sciences workshop, 2004). At high pressure (>20 MPa) and with ice temperatures close to the pressure-melting point, water can be produced by cutting and refrozen ice appears on various parts of the drill head. This greatly affects the functioning of the drill and especially the drilling rate. Within a few metres the penetration dropped from $200 \mathrm{~m}$ per week to a few metres per week.

\section{SEASON 6: 2001/02 (1458-2871 m)}

The first runs of the sixth season saw a series of breakdowns in several parts of the drilling equipment (winch, tower, drill). Malfunctioning of the embedded electronics made the risk of losing the drill too high to continue drilling. In order to improve communication with the drill, we changed the old four-wire cable (shortened by $783 \mathrm{~m}$ when it was cut at the surface from the stuck drill in 1998) to a one-wire coaxial cable type (Gundestrup and Johnsen, 2002). A three-wheeled capstan and a pre-tensioning system were used to wind the cable on the winch. This 2 day operation ( 1 day to set up and 1 day for winding) went smoothly. The cable was wound at a rate of $0.3 \mathrm{~m} \mathrm{~s}^{-1}$ under a tension of $5000 \mathrm{~N}$. The new cable provided improved communication, and the drill performed with no data losses. The reduced operator stress at the control console was much appreciated by the drillers. Core production was excellent, reaching $2.8 \mathrm{~m}$ length on average, giving a weekly production of $191 \mathrm{~m}$ of core, working three shifts around the clock. In the most efficient week (interval 2230-2480 m), production reached $250 \mathrm{~m}$. Below $2550 \mathrm{~m}$ depth, deposition of chips on top of the core was noticed, preventing an easy start to the run. Below $2700 \mathrm{~m}$ depth, runs became more difficult, shorter and irregular. On each run there was some refrozen ice on the cutters, under the penetration shoes and on the pump drive shaft.

The inclination from vertical was very good down to $2400 \mathrm{~m}$, not exceeding $0.34^{\circ}$. Below this depth, it steadily increased to $3.70^{\circ}$ at $2871 \mathrm{~m}$, the final depth for the sixth season. Unsuccessful efforts were made to stop this increase of inclination by sharpening cutters, monitoring more closely the weight on the cutters and improving core-barrel guidance. Seasons 5 and 6 showed the EPICA drill's ability to penetrate well. In addition, the drill became more reliable and the pump was more efficient, leaving fewer chips at the bottom of the hole.

\section{SEASON 7: 2002/03 (2871-3200 m)}

Two new drill-head designs were tested at the beginning of the seventh season. The aim was to improve the fluid circulation at the cutters' edge. It was thought that this would prevent the ice build-up experienced during the previous season. None of the designs was successful, despite good results in the laboratory in Grenoble, France. The three most obvious differences between the laboratory and the field tests were: (1) the fluid was cleaner in the laboratory; (2) the fluid pressure in the laboratory was nearly atmospheric versus $25 \mathrm{MPa}$ in the hole; (3) the drill was rigidly connected in the laboratory but was at the end of a long elastic cable in the field. By experience, we know that chips and fluid should be mixed together before transportation, especially when there is only one pump for several cutters (Johnson and other, 2007). Both new designs were weak on that specific point, so the original EPICA drill head was used rather than the newer designs. At $57 \mathrm{rpm}$, with $45^{\circ}$ face angle cutters and $3 \mathrm{~mm}$ pitch, production averaged $20 \mathrm{~m} \mathrm{~d}^{-1}$. At $3119 \mathrm{~m}$, however, production suddenly dropped to near standstill. This dramatic change corresponded to a $0.15^{\circ} \mathrm{C}$ ice temperature increase to $-6.28^{\circ} \mathrm{C}$. Ice chips were frozen onto the shoes and cutters, as though the cutting process had created a mixture of ice and water, which had then refrozen just millimetres away. Several days were spent trying to overcome this problem by changing the cutters, the cutting pitch, the 
drill-motor rpm and even switching to a shorter version of the EPICA drill in an attempt to lessen pump losses.

After discussion among the crew on site and consultation overseas, it was decided to use ethanol-water solution (EWS) to prevent the water produced by the cutting process from refreezing. Previously, for other projects, EWS was used as the borehole fluid (Zagorodnov and others, 1994). For EDC2, EWS was prepared at a concentration to be at equilibrium at ice bottom temperature. EWS was injected at the bottom with a special heated tank built on site, connected below the motor section in place of the usual lower part of the drill (chips chamber and core-barrel section). A total volume of $17 \mathrm{~L}$ of ethanol and $90 \mathrm{~L}$ of water was delivered to the bottom of the hole in 16 different runs. Each injection of EWS enabled several drilling runs. A total of 99 runs were performed in this way for $80 \mathrm{~m}$ of core collection. Most of the time, the core was frozen inside the core barrel and electric heat guns were used to free it. In addition, the chips were frozen inside the chips chamber. All this affected the quality of the ice core, reduced the diameter and created additional cracks from the heat guns. The use of EWS was not an ideal solution to the problem of drilling 'warm ice'.

\section{SEASON 8: 2003/04 (3200 m; NO DRILLING)}

At the end of the seventh season, while being returned to Europe, some of our drilling equipment (drill heads, electronic section and logging equipment) was stolen. A non-drilling season was required while the missing equipment was replaced. A temperature profile of the hole was obtained by a reduced crew of two.

\section{SEASON 9: 2004/05 (3200-3270 m)}

A new log of the hole (diameter, inclination, orientation, pressure and temperature) showed a few spots with narrow diameter. These narrow spots were reamed with the long version of the EPICA drill ( $3.5 \mathrm{~m}$ core). Seismic measurements were also performed to determine the ice thickness more accurately: $3273 \mathrm{~m}$ vertical depth (personal communication from J. Schwander, 2006). Dead weights were added to the short version of the EPICA drill ( $1.5 \mathrm{~m}$ core) to allow a higher descent speed and more stable drilling. We decided not to use the heated tank that had been used during the seventh season to inject EWS at the bottom of the hole. Instead, taking advantage of the North Greenland Icecore Project (NorthGRIP) experience during the 2003 and 2004 summer seasons (Johnsen and others, 2007), a plastic bag filled with $1.4 \mathrm{~L}$ of EWS, $50 \%$ in volume, was attached, for each run, to the motor-drive shaft inside the chips chamber. The bag, scratched by a sharpened screw, released the solution at the start of drill-motor rotation.

Core recovery was improved by putting the entire lower part of the drill, disconnected from the motor section, inside a D30 fluid bath upon its return to the surface. The bath was regulated to the ice bottom temperature. Ice core and ice chips were free and easy to recover after 45 min immersion in the bath. With this gentler treatment at the surface, the core showed fewer cracks and core quality slightly improved.

An average of $8 \mathrm{~m}$ of core was drilled every day, working 18 hours a day. More than $60 \mathrm{~m}$ were drilled, down to $3264.78 \mathrm{~m}$, in 13 days. The temperature at this depth was
Table 1. EDC2 hole measurements

\begin{tabular}{cccccc}
\hline Season & $\begin{array}{c}\text { Final } \\
\text { depth }\end{array}$ & $\begin{array}{c}\text { Bottom } \\
\text { temperature }\end{array}$ & $\begin{array}{c}\text { Max. } \\
\text { diameter }\end{array}$ & $\begin{array}{c}\text { Max. } \\
\text { inclination }\end{array}$ & $\begin{array}{c}\text { Bottom } \\
\text { pressure } \\
\text { m }\end{array}$ \\
& ${ }^{\circ} \mathrm{C}$ & $\mathrm{mm}$ & $\circ$ & $\mathrm{MPa}$ \\
\hline $2000 / 01$ & 1458 & no data & 134.0 & 0.34 & 12.7 \\
$2001 / 02$ & 2871 & -11.5 & 134.0 & 4.00 & no data \\
$2002 / 03$ & 3200 & -4.2 & 134.7 & 4.70 & 28.6 \\
$2004 / 05$ & 3270 & -2.3 & over-range & 4.70 & 29 \\
\hline
\end{tabular}

$-2.64^{\circ} \mathrm{C}$. Below this depth, and within only $2 \mathrm{~m}$, drilling became unstable. Different changes were tried without success (shoes, pitch, cutters' face angle, EWS concentration and fluid circulation at the start of the run). Penetration became very difficult: $5.4 \mathrm{~m}$ for 35 runs performed from 3264.78 to $3270.20 \mathrm{~m}$. The temperature was $-2.34^{\circ} \mathrm{C}$, a difference from the pressure-melting point of $0.34^{\circ} \mathrm{C}$. We noticed more than $1 \mathrm{~m}$ of chips deposited on top of the core in between two runs. For some runs, the amount of chips collected inside the chips chamber was far too large for the amount of ice chips cut. On the last run, at $3270.2 \mathrm{~m}$ depth, the drill became stuck without warning. Pulling up to $25000 \mathrm{~N}$ tension on the cable did not move it. Frozen ethylene glycol pellets $(2 \mathrm{~kg})$ were thrown into the hole (Gundestrup and others, 2002), and the drill was free 4 hours later. We pulled it to the surface without further difficulty. To clean the bottom of the hole of ethylene glycol slush required 14 runs, corresponding to $220 \mathrm{~L}$ of slush, more than ten times the original amount poured in.

In response to various concerns of the EPICA steering committee (environmental issues and drill safety), the drilling activity was stopped at $3270.2 \mathrm{~m}$ depth, an estimated $16 \mathrm{~m}$ above bedrock.

\section{HOLE MEASUREMENTS}

At the beginning and end of every season up to 2002/03, the hole was logged with the French logger (Lefebvre and others, 2002). As the logger made in Grenoble was stolen in 2003, the last measurement was performed with the Danish logger (Gundestrup and others, 1994). The maximum hole diameter of $134 \mathrm{~mm}$ at $328 \mathrm{~m}$ depth (Table 1) was obtained after use of a special, conical, tool to fish up tiny plastic pieces coming from the motor-shaft ball-bearing cage. Otherwise, the diameter was very regular, as expected for an electromechanical drill, and varied only a few tenths of a millimetre around $129.6 \mathrm{~mm}$, which is the nominal hole diameter. The over-range diameter obtained in 2004/05 was a consequence of the EWS used in drilling 'warm ice'. The inclination is very stable around $0.34^{\circ}$ down to $2400 \mathrm{~m}$ depth, and then increases steadily to $4.7^{\circ}$ near the bottom, in spite of efforts made to reduce it (cutter changes, cutter sharpening, and changes of core-barrel polyethylene spiral guiding pieces). The reason for this inclination increase has not been clearly identified.

\section{DRILLING DATA}

The drilling took five seasons (including the pilot hole), and the hole was completed on 21 December 2004 after 


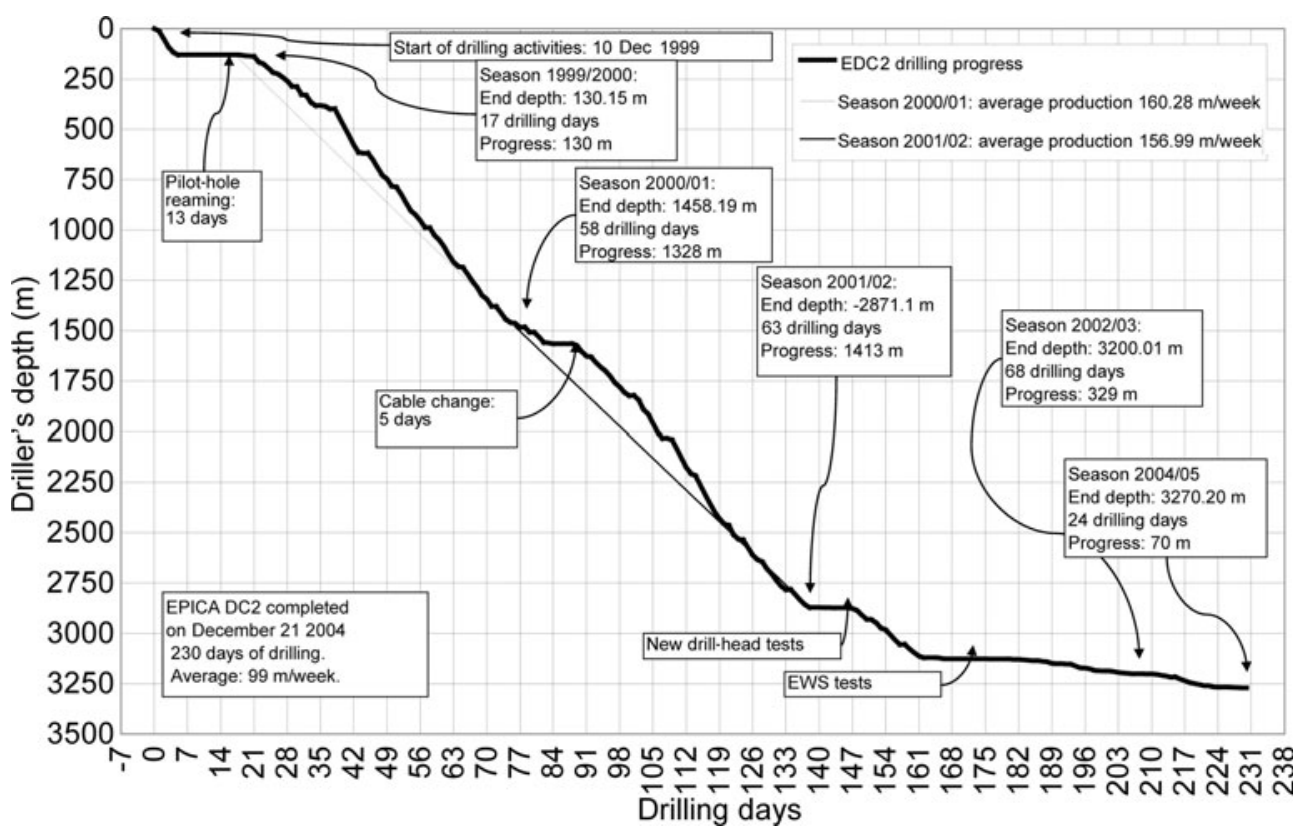

Fig. 1. EDC2 hole drilling progress.

230 drilling days. The weekly average core production was $99 \mathrm{~m}$, and the highest production achieved was $250 \mathrm{~m}$ (Fig. 1). A weekly average of 41 runs was performed, with a maximum of more than 75 runs. The average core length varied seasonally (Fig. 2). The maximum seasonal average, $2.8 \mathrm{~m}$, occurred during the sixth season (1458-2870 m), when many of the cores were around $3.2 \mathrm{~m}$ in length. In the final season, when 'warm ice' was drilled, core-length average dropped to $0.58 \mathrm{~m}$. Examination of core-break tensions shows a slight decrease with depth (Fig. 3). In the very last runs, core-break forces were very high. For those runs it is difficult to determine whether the drill was close to being stuck, but most likely the run was ended in a packing situation around the drill head.

\section{DRILLING FLUID}

The fluid used for the EDC2 hole is a two-component fluid: Exxsol D30 and HCFC-141b mixed to give a density equal to the ice density (Talalay and Gundestrup, 2002). Some efforts were made on site to reduce the drilling-fluid consumption. The percentage of excess fluid required varied greatly from season to season. The percentage of HCFC$141 \mathrm{~b}$ used and mixed with Exxsol D30 also increased

Table 2. EDC2 hole drilling fluid data

\begin{tabular}{cccccc}
\hline Season & Progress & $\begin{array}{c}\text { Drill } \\
\text { travelling } \\
\text { distance }\end{array}$ & $\begin{array}{c}\text { Fluid- } \\
\text { consumption }\end{array}$ & $\begin{array}{c}\text { Fluid- } \\
\text { consumption } \\
\text { excess }\end{array}$ & $\begin{array}{c}\text { HCFC-141b } \\
\text { used in fluid }\end{array}$ \\
& $\mathrm{m}$ & $\mathrm{km}$ & $\mathrm{L} \mathrm{m}^{-1}$ & $\%$ & $\%$ \\
\hline $2000 / 01$ & 1328 & 794 & 19 & 44 & 35 \\
$2001 / 02$ & 1413 & 2200 & 18 & 41 & 42 \\
$2002 / 03$ & 329 & 2471 & 29 & 123 & 43 \\
$2004 / 05$ & 70 & 770 & 54 & 315 & 44 \\
\hline
\end{tabular}

(Table 2). The data given are based upon the total number of drums used on site for the entire drilling activity. Starting from $44 \%$ in the first season, the fluid excess consumption decreased after an effort was made to collect drilling fluid at the surface, then increased again, reaching $315 \%$ in the final season due to 'warm-ice' drilling activities, including use of the drilling-fluid bath. At $13.19 \mathrm{~L} \mathrm{~m}^{-1}$, the theoretical volume of the hole is $45220 \mathrm{~L}$. The total fluid consumption was just over $65000 \mathrm{~L}$.

\section{EPICA DOME C DRILLING EQUIPMENT CHARACTERISTICS EPICA drill}

Drill head

Number of cutters 3

Outer diameter $(\mathrm{mm}) \quad 129.6$

Inner diameter $(\mathrm{mm}) \quad 98$

Face angle $\left(^{\circ}\right)$

Clearance angle $\left(^{\circ}\right) \quad 12$

Number of core dogs 3

Core-barrel inner tube

Outer diameter $(\mathrm{mm}) \quad 104$

Inner diameter $(\mathrm{mm}) \quad 102$

Length $(\mathrm{m}) \quad 3.75$

Rotation speed (rpm) 5-83

Rotation speed used all

the time for drilling (rpm) 57

Equipped with bayonet on top part for quick release

Pump

Type

Double-piston (six

Stroke length $(\mathrm{mm})$ valves per piston)

Pump flow $\left(\mathrm{m}^{3} \mathrm{~s}^{-1}\right)$

$(0.25-0.34) \times 10^{-3}$ 


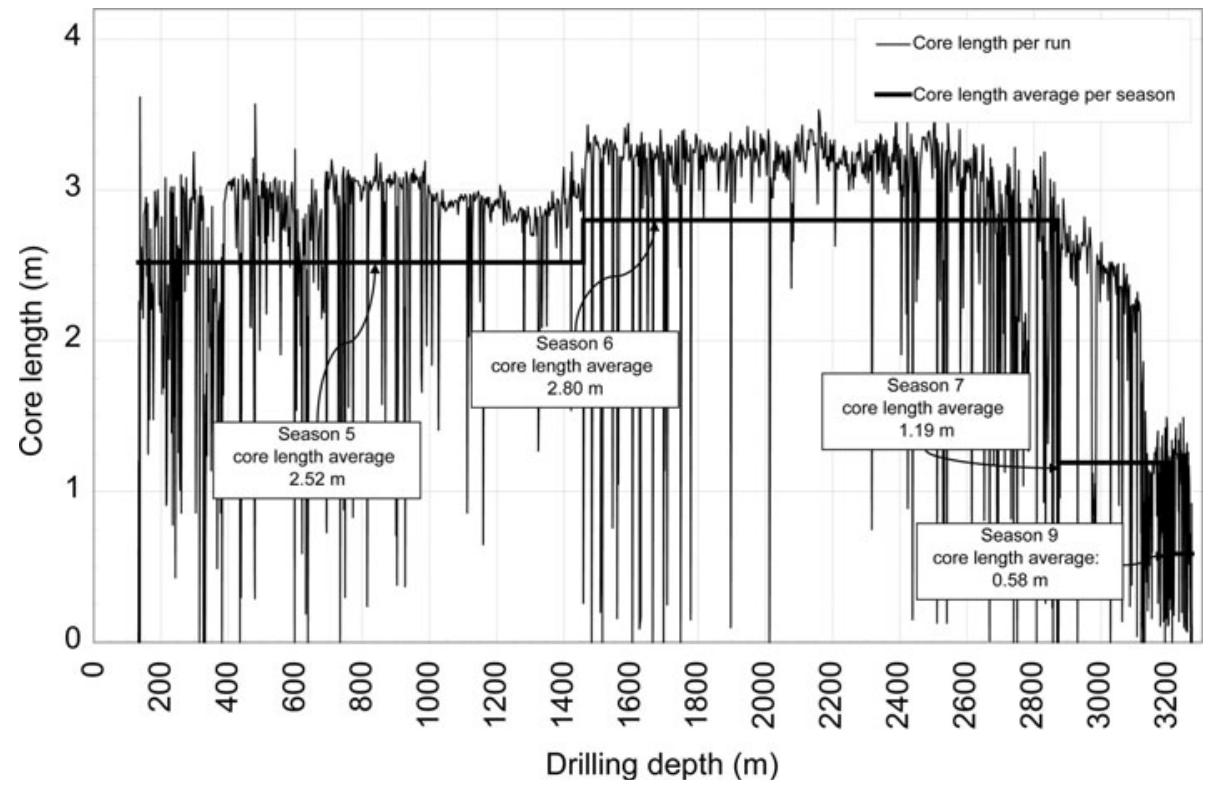

Fig. 2. EDC2 core length vs depth.

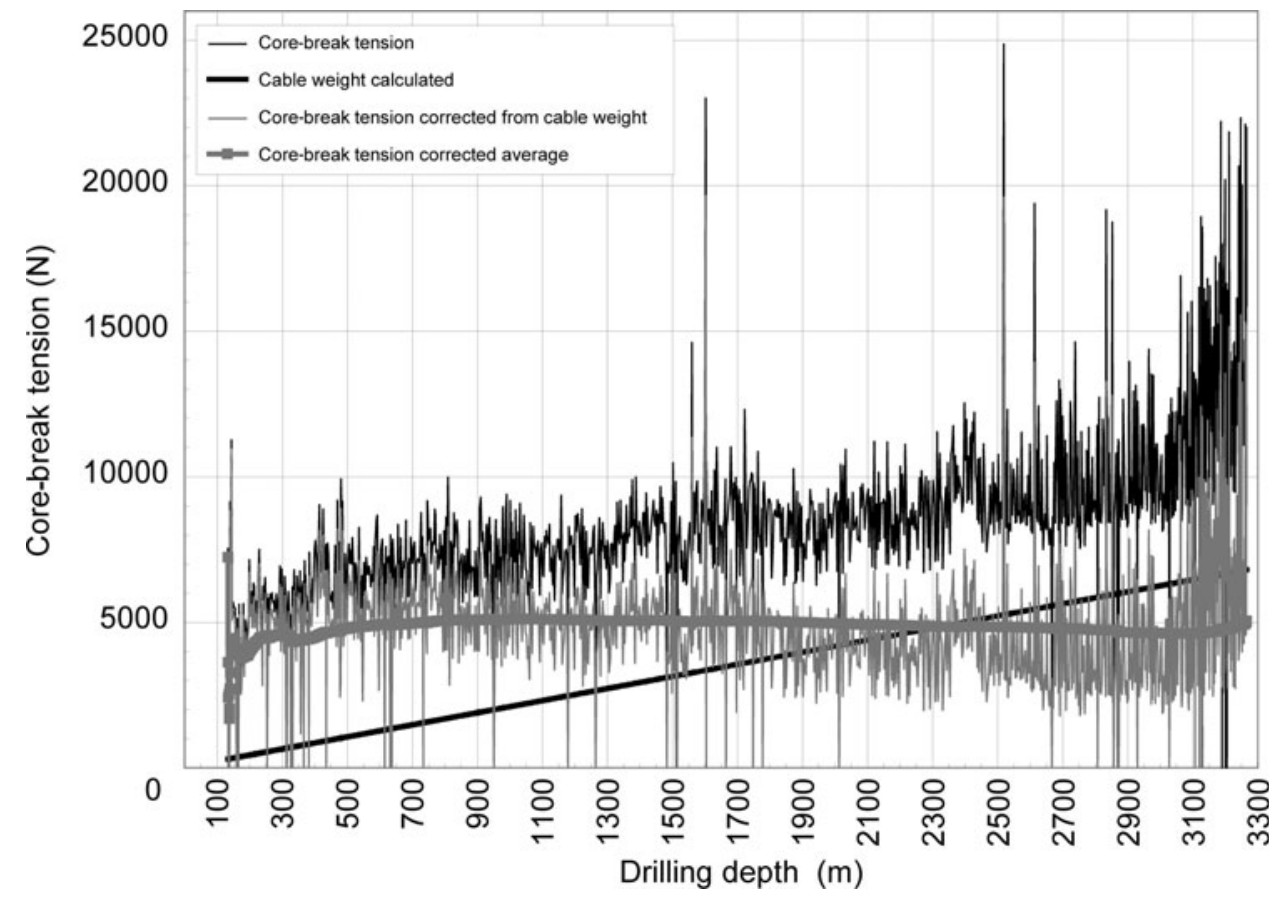

Fig. 3. EDC2 hole: core-break tension vs depth.

Chips chamber

Outer diameter $(\mathrm{mm})$ Inner diameter (mm)

Length (m)

Pressure tube

Outer diameter $(\mathrm{mm})$ Inner diameter $(\mathrm{mm})$ Length $(\mathrm{m})$

Pressure tightness (MPa)
Motor

114.3

110.3

4.00

Type

Voltage (V)

Brushless

Power (W)

Rotation speed (rpm)

900

Torque (Nm)

4000

1.9

Reducer

Type

Planetary gear head

Ratio 


\section{Drill control \\ Commands \\ Controlled parameters}

Parameters for information

\section{Anti-torque}

Type

\section{Drilling tent}

Length $(\mathrm{m})$

Width $(\mathrm{m})$

Height $(\mathrm{m})$

\section{Drilling tower}

Height (m)

Maximal force

on top sheave $(\mathrm{kN})$

Rotation

\section{Winch}

Power (kW)

Motor type

Motor max. torque $(\mathrm{N} \mathrm{m})$

Speed control regulation $\left(\mathrm{m} \mathrm{s}^{-1}\right)$

Max. torque

Cable capacity (m)

Total weight $(\mathrm{kg})$

\section{Cable}

Type

Conductor

Shield

Armour

Diameter (mm)

Elastic limit $(\mathrm{kN})$

Weight $\left(\mathrm{kg} \mathrm{m}^{-1}\right)$

\section{Drilling fluid}

Type

Density, Exxsol D30 $\left(\mathrm{kg} \mathrm{m}^{-3}\right)$ Density, HCFC-141b $\left(\mathrm{kg} \mathrm{m}^{-3}\right)$ Viscosity (cSt)
Drill motor ON/OFF

Motor current motor rotation speed, penetration speed, cable load, cutter load Temperatures, pressures, inclination, orientation, depth, length of run

Three leaf springs, ISTUK type (Gundestrup and others, 1984)

6

7

80

From vertical to horizontal position

15

Tri-phase

98

$10^{-4}$ to 1.4

Hold at 0 speed

4000

2000

Coaxial

1

1

Double external 7.29

29

0.2 (Gundestrup and Johnsen, 2002)

Mixture of Exxsol D30 + HCFC-141b

807 at $-53^{\circ} \mathrm{C}$

1307 at $-53^{\circ} \mathrm{C}$

4 at $-53^{\circ} \mathrm{C}$

\section{ACKNOWLEDGEMENTS}

We express our sincere gratitude to the EPICA project members for their support and cooperation during the Dome $\mathrm{C}$ drilling operation, and to Institut Polaire FrançaisEmile Victor (IPEV), Brest, France, and Ente per le Nuove Tecnologie, I'Energia e I'Ambiente (ENEA), Rome and Bologna, Italy, for excellent logistic support. We express special thanks to V. Zagorodnov for fruitful discussions about EWS, and the data he generously gave us. We thank the 19 drillers, from eight different countries, for the accomplishment of the EDC2 hole and for the great human experience we have shared. We thank especially our colleagues at the Laboratoire de Glaciologie et Géophysique de I'Environnement (LGGE) workshop. This work is a contribution to the European Project for Ice Coring in Antarctica (EPICA), a joint European Science Foundation/European Commission scientific programme, funded by the European Union and by national contributions from Belgium, Denmark, France, Germany, Italy, the Netherlands, Norway, Sweden, Switzerland and the United Kingdom. The main logistic support was provided by IPEV and Programma Nazionale di Ricerche in Antartide (at Dome C) and the Alfred-Wegener-Institut (in Dronning Maud Land). This is EPICA publication No. 208. Additional funding was provided by the Sixth Framework Programme (FP6) Specific Targeted Research Project (STREP) EPICA-MIS.

\section{REFERENCES}

Augustin, L. and A. Antonelli. 2002. The EPICA deep drilling program. Mem. Natl. Inst. Polar Res., 56, Special Issue, 226-244.

Gundestrup, N.S. and S.J. Johnsen. 2002. Attenuation of drill cables. Mem. Natl. Inst. Polar Res., 56, Special Issue, 206-208.

Gundestrup, N.S., S.J. Johnsen and N. Reeh. 1984. ISTUK: a deep ice core drill system. CRREL Spec. Rep. 84-34, 7-19.

Gundestrup, N.S., H.B. Clausen, and B.L. Hansen. 1994. The UCPH borehole logger. Mem. Natl. Inst. Polar Res., 49, Special Issue, 224-233.

Gundestrup, N.S., S.J. Johnsen, S.B. Hansen, H. Shoji, P. Talalay and F. Wilhelms. 2002. Sticking deep ice core drills: why and how to recover. Mem. Natl. Inst. Polar Res., 56, Special Issue, 181-195.

Johnsen, S.J. and 16 others. 2007. The Hans Tausen drill: design, performance, further developments and some lessons learned. Ann. Glaciol., 47, 89-98.

Lefebvre, E., L. Augustin, and M. Maitre. 2002. The EPICA borehole logger. Mem. Natl. Inst. Polar Res., 56, Special Issue, 264-274.

Talalay, P.G. and N.S. Gundestrup. 2002. Hole fluids for deep ice core drilling. Mem. Natl. Inst. Polar Res., 56, Special Issue, 148-170.

Zagorodnov, V.S, J.J. Kelley and O.V. Nagornov. 1994. Drilling of glacier boreholes with a hydrophilic fluid. Mem. Natl. Inst. Polar Res., 49, Special Issuse, 153-164. 